\title{
RESPONS WANITA TANI PADA PEMBUATAN KELUWAK INSTAN SEBAGAI PENGAWET ALAMI
}

\section{Response of Farming Women on Making of Instant Keluwak as Natural Preserved}

\author{
Ummu Aimanah, Munira, dan Arief Sirajuddin \\ Polteknik Pembangunan Pertanian (Polbangtan) Gowa \\ e-mail: ummuitpn_unhas@yahoo.co.id
}

Received: 4 Februari 2020; Accepted: 29 Maret 2020; Published: 30 Juni 2020

\begin{abstract}
ABSTRAK
Keluwak adalah salah satu bumbu yang biasa digunakan untuk berbagai makanan Indonesia. Keluwak berbentuk seperti batu dan mengeluarkan warna hitam alami. Tujuan Penelitian ini adalah untuk mengetahui cara pembuatan keluwak instan sebagai pengawet alami dan untuk mengetahui analisa kandungan kadar air, tanin dan kadar asam sianida serta untuk mengetahui respon wanita tani pada pembuatan keluwak instan sebagai pengawet alami. Parameter pengamatan A. Keluwak kontrol, B. keluwak dan Gula pasir 1:1, C. Keluwak 2:1. Hasil analisa kandungan kadar air tertinggi terdapat pada pelakuan B yaitu perlakuan perbandingan daging buah keluwak dan gula pasir 1:1, yaitu sebesar $8.89 \%$, sedangkan kadar air terendah terdapat pada perlakuan kontrol yaitu sebesar 7\%. Kadar tanin tertinggi terdapat pada pelakuan B yaitu perlakuaan perbandingan daging buah keluwak dan gula pasir 1:1, yaitu sebesar 29.4\%, sedangkan kadar tanin terendah terdapat pada perlakuan kontrol yaitu sebesar $24.63 \%$. Kandungan Asam Sianida tertinggi pada perlakukan B yaitu $27.85 \%$ dan terendah pada perlakuan kontrol A $20.45 \%$. Efektivitas penyuluhan kategori efektif dengan persentase skor $68.50 \%$.
\end{abstract}

Kata kunci: Keluwak, pengawet, dan penyuluhan

\begin{abstract}
Keluwak is one of the spices commonly used for various Indonesian foods. Keluwak shaped like a stone and emit a natural black color. The purpose of this study was to determine how to make instant keluwak as a natural preservative and to know the analysis of water content, tannins and cyanide acid levels and to determine the response of farmer women to making instant shellfish as a natural preservative. Observation parameters A. Control keluwak, B. Keluwak and granulated sugar 1:1, C. Keluwak and granulated sugar $2: 1$. The results of the analysis of the highest water content content is in the treatment $B$, namely the ratio treatment of keluwak and sugar 1:1, which is equal to $8.89 \%$, while the lowest water content is at control treatment that is equal to $7 \%$. The highest tannin content was found in treatment B, which was the comparison treatment of the keluwak and granulate sugar 1:1 sugar, which was $29.4 \%$, while the lowest tannin content was in the control treatment that was $24.63 \%$. The highest content of cyanide acid in treatment $B$ was $27.85 \%$ and the lowest was in the control treatment $A 20.45 \%$. The effectiveness of effective category counseling with a percentage of $68.50 \%$.
\end{abstract}

Keywords: Keluwak, preservatives, and counseling

\section{PENDAHULUAN}

Makassar merupakan salah satu daerah yang menawarkan beragam kuliner. Makanan khas daerah ini adalah coto, konro, pallu basa, pisang ijo, pallu butung, dan masih banyak lagi.
Konro merupakan salah satu makanan khas Makassar yang sangat digemari oleh warga Sulawesi Selatan. Selain konro dan coto serta sejumlah makanan khas tersebut tadi, rawon merupakan salah satu makanan yang sangat digemari oleh masyarakat, dan hampir selalu ada 
disajikan pada saat ada acara keluarga dan biasa pula disajikan pada saat perayaan Idul Fitri atau Idul Adha.

Kabupaten Soppeng merupakan daerah di Sulawesi Selatan yang cukup banyak menghasilkan keluwak. Di daerah ini keluwak biasanya dimanfaatkan sebagai salah satu lauk dalam makanan. Keluwak sering kali dimasak bersama ikan bandeng, cakalang, dan ikan gabus, dan masakan itu dinamakan "nasu kaloa". Selain itu keluwak biasanya dijadikan sambal dan ditumis.

Menurut Haryanto dan Subiandono (2009), pohon picung atau kluwak selain sebagai bumbu masak dapur, biji buah picung juga bisa dimanfaatkan sebagai pengawet alami ikan segar. Keluwak ini memberikan rasa yang khas dalam pembuatan rawon. Keluwak (Pangium edule Reinw) adalah biji dari tanaman pohon kepayang. Pohonnya bisa mencapai setinggi pohon durian. Bentuk buah keluwak seperti buah sukun, di dalamnya terdapat biji, biji inilah yang diolah menjadi keluwak yang dapat dimanfaatkan sebagai bumbu dan pewarna masakan. yang sudah tua berwarna hitam dan menerbitkan rasa asam manis dan pedas. Dibalik kulitnya yang keras terdapat daging berwarna kehitaman. Daging keluwak inilah merupakan bumbu utama yang menimbulkan aroma rawon dan warna kuah yang berkilau keemasan.

Penggunaan daging biji keluwak sebagai pengawet karena daging dalam biji keluwak mengandung bahan kimia yang sangat beragam dan berhubungan dengan pengendalian perkembangbiakan bakteri pada ikan dan daging yaitu asam sianida, tanin dan senyawa-senyawa lainnya yang mampu memberikan efek awet pada ikan dan daging. Kandungan asam sianida (HCN) terdapat hampir di seluruh bagian pohon keluwak baik daun, biji, buah, kulit kayu dan akar namun dalam daging biji pangi yang sangat tinggi. Kadar asam sianida ini memang tidak dapat dikesampingkan dapat membahayakan dan cukup beracun bagi manusia jika dikonsumsi namun hal ini dapat diatasi dengan proses pemanasan selama 2-3 hari. Sifat asam sianida yang mudah menguap pada suhu $26^{\circ} \mathrm{C}$ ditambah dengan melarutkan dalam air, sehingga proses pencucian dalam air dan pemanasan merupakan cara efektif untuk menghilangkan kadar asam pada daging biji keluwak.

Biji keluwak berwarna putih, dengan proses pemeraman keluwak bisa menjadi berwarna kehitaman. Penggunaanya dengan cara diambil dagingnya kemudian dihaluskan. Keluwak yang sudah dihaluskan ini bisa langsung dimasukkan ke dalam masakan. Hidangan yang biasanya menggunakan keluwak sebagai bumbunya adalah rawon, sup konro atau brongkos. Dengan menambahkan keluwak, rasa masakan akan lebih lezat, gurih dan kental. Potensi keluwak sebagai pengawet alami dalam bentuk bubuk instan yang memudahkan ibu rumah tangga dalam pemberian bumbu masakan. Dengan adanya penelitian ini akan memberikan respon wanita tani dalam pemanfaatan bubuk instan keluwak.

Kadar air merupakan banyaknya air yang terkandung dalam bahan pangan yang dinyatakan dalam persen. Kadar air dalam bahan pangan ikut menentukan kesegaran dan daya awet bahan pangan tersebut. Kadar air dalam bahan pangan sangat berperan untuk menjaga konsistensi tekstur. Semakin tinggi konsentrasi gula yang ditambahkan, maka kadar air selai semakin rendah. Menurut Siregar dkk (2007), gula memiliki sifat osmosis (menyerap air) sehingga kadar air dalam bahan semakin menurun seiring bertambahnya konsentrasi gula. Gula bersifat osmosis sehingga dapat menarik air dari dalam bahan sehingga kadar air bahan menjadi rendah dan tidak tersedia untuk digunakan mikroorganisme. Selain itu menurut Desrosier (2008), kadar air produk pangan dipengaruhi oleh proses pemasakan karena kadar air selai akan mengalami penurunan selama proses pemasakan. Proses yang terjadi yaitu panas yang ditimbulkan oleh pemasakan masuk ke dalam bahan yang kemudian menggantikan kandungan air yang keluar menjadi uap.

\section{METODE PELAKSANAAN}

\section{Tempat dan waktu}

Penelitian ini dilaksanakan pada Laboratorium Pengolahan Hasil Pertanian Politeknik Pembangunan Pertanian (Polbangtan) Gowa kelompok wanita tani Romanglompoa pada tanggal 2 April-Oktober 2019.

\section{Bahan dan alat}

Bahan-bahan yang digunakan adalah biji keluwak, gula pasir, air, abu sekam bahan analisa kadar, kadar tanin dan kadar asam sianida. Alatalat yang digunakan dalam penelitian ini adalah blender, talenan, wajan, pengaduk, kompor, 
pisau, timbangan, gelas ukur, saringan, alat analisa kadar air, kadar tanin, dan kadar asam sianida.

\section{Prosedur}

Pembuatan keluwak adalah:

1. Dilakukan perendaman keluwak, dicuci biji keluwak, rebus selama 1 jam, keringkan.

2. Ambil mangkuk bertutup, atur abu sekam, letakan kluwak dan tutup kembali bagian atasnya dengan abu sekam hingga seluruh permukaan tertutupi abu sekam. Peram selama 15 hari, ambil biji kluwak, bersihkan dari abu sekam. Pecahkan cangkangnya dan ambil daging biji keluwak. Pewarna hitam keluwak siap digunakan.

3. Keluwak yang ada selanjutkan dicacah dan disaring kemudian dimasak dengan perlakuan (A), tanpa perlakuan (kontrol); (B) keluwakgula pasir 1:1; (C) keluwak-gula pasir 2:1 sesuai perlakuan masing-masing.

4. Setelah itu dimasak sampai mengering dan menjadi bubuk. Keluwak instan yang dihasilkan kemudian dianalisa kadar air, kadar tanin dan kadar asam sianida.

\section{Rancangan percobaan}

Penelitian ini dilakukan dengan rancangan acak lengkap (RAL) dengan 3 (tiga) kali ulangan.

\section{Parameter pengamatan}

Analisa kandungan kadar air dan analisa kandungan kadar tanin adalah sebagai berikut:

1. Kadar air

Kadar air dapat dihitung menggunakan rumus sebagai berikut:

Kadar air basis basah $\left(\frac{\mathrm{g}}{100 \mathrm{~g}}\right.$ bahan basah $)=\frac{\mathrm{W}-(\mathrm{W} 1-\mathrm{W} 2)}{\mathrm{W}} \times 100$

Kadar air basis kering $\left(\frac{\mathrm{g}}{100 \mathrm{~g}}\right.$ bahan kering $)=\frac{\mathrm{W}-(\mathrm{W} 1-\mathrm{W} 2)}{\mathrm{W} 1-\mathrm{W} 2} \times 100$

\section{Keterangan:}

W : bobot sampel sebelum dikeringkan (gr)

W1 : bobot sampel dan cawan kering (gr)

W2 : bobot cawan kosong (gr)

2. Kadar tannin

Kadar tanin dapat ditetapkan dengan Metode

Gravimetri. Analisis dengan menggunakan metode gravimetri adalah cara analisis kuantitatif berdasarkan berat tetap (berat konstan)-nya. Reagen atau pereaksi yang ditambahkan adalah berlebih untuk menekan kelarutan endapan.

3. Kadar asam sianida

Sebanyak 20 gram sampel yang sudah dihaluskan dimasukkan ke dalam beaker glass, kemudian ditambahkan $100 \mathrm{ml}$ aquades dan direndam selama 2 jam; kemudian ditambahkan lagi $100 \mathrm{ml}$ aquadest dan didestilasi uap; destilasi ditampung didalam labu erlenmeyer yang sudah diisi 25 $\mathrm{ml} \mathrm{AgNO}_{3} 0.02 \mathrm{~N}$ dan $1 \mathrm{ml} \mathrm{HNO}_{3}$ (1:4); setelah destilat benar-benar habis (tak menguap lagi), destilasi dihentikan; lalu diukur volume destilat yang diperoleh; ke dalam labu erlenmeyer yang lain, destilat yang diperoleh dibagi, masing-masing erlenmeyer berisi $25 \mathrm{ml}$ destilat yang diperoleh, kemudian dititrasi dengan KSCN sampai timbul warna merah.

\section{Pelaksanaan penyuluhan}

Penerapan rancangan penyuluhan berdasarkan pertimbangan teknis, kondisi sosial dan ekonomi serta karakteristik masyarakat untuk membentuk masyarakat tani yang berpengetahuan.

\section{Evaluasi penyuluhan pertanian}

Untuk mengetahui tingkat respon wanita tani terhadap materi adalah dengan pengukuran terhadap indikator dengan menggunakan rating scale atau skala nilai, kemudian ditabulasi dan diolah dengan menggunakan garis continum.

Pengukuran efektivitas penyuluhan (Ginting, 1991) dengan rumus :

$$
\mathrm{EP}=\frac{\mathrm{Ps}-\mathrm{Pr}}{\mathrm{N} 3 \mathrm{Q}-\mathrm{Pr}} \times 100 \%
$$

Keterangan:

Ps : Post test

Pr : Pre test

$\mathrm{N}$ : Jumlah responden

3 : Nilai tertinggi

Q : Jumlah pertanyaan

Nilai presentasi efektivitas tingkat pengetahuan adalah

$<32 \%$ : Kurang efektif

32-64\% : Cukup efektif

$>65 \%$ : Efektif 


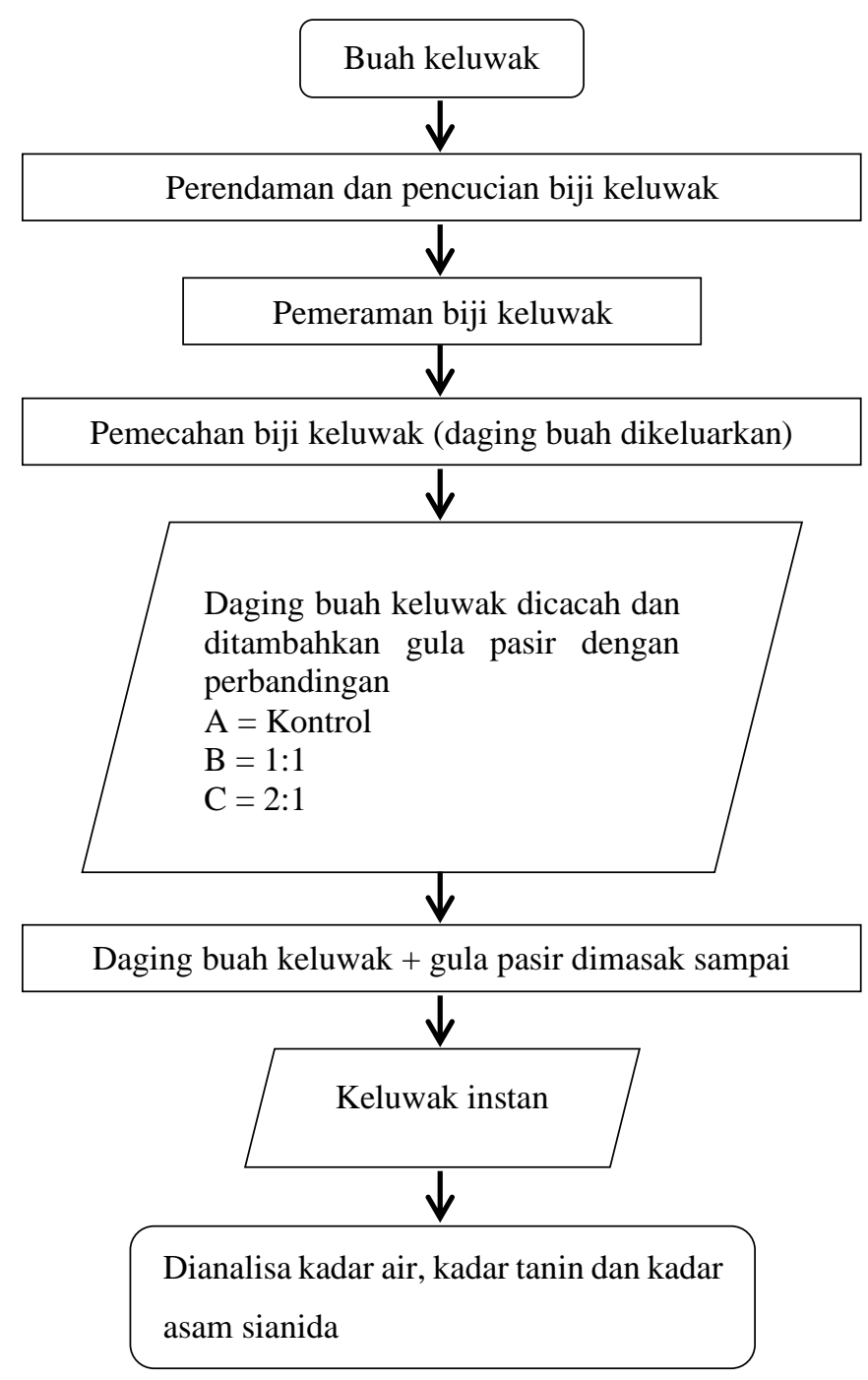

Gambar 1. Diagram alir pembuatan bubuk keluwak instan

\section{HASIL DAN PEMBAHASAN}

\section{Kadar air}

Analisa kadar air dimaksudkan untuk mengetahui perubahan kandungan air pada keluwak instan yang dihasilkan dengan pencampuran daging buah keluwak dan gula pasir, karena kadar air menentukan daya awet keluawak instan tersebut.

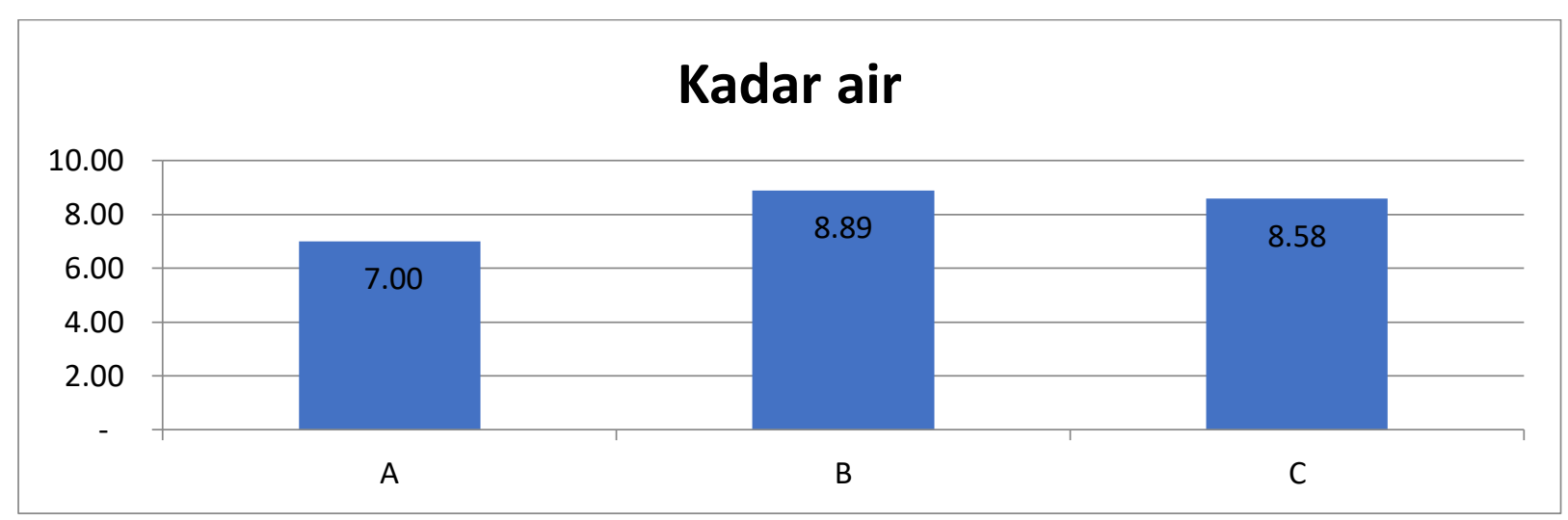

Gambar 2. Kadar air keluwak instan 
Kadar air tertinggi terdapat pada pelakuan B yaitu perlakuaan perbandingan daging buah keluwak dan gula pasir 1:1, yaitu sebesar $8.89 \%$, sedangkan kadar air terendah terdapat pada perlakuan kontrol yaitu sebesar $7 \%$. Hal ini disebabkan gula bersifat osmosis sehingga dapat menarik air dari dalam bahan sehingga kadar air bahan menjadi rendah dan tidak tersedia untuk digunakan mikroorganisme. Menurut Siregar dkk (2007), gula memiliki sifat osmosis (menyerap air) sehingga kadar air dalam bahan semakin menurun seiring bertambahnya konsentrasi gula. Gula bersifat osmosis sehingga dapat menarik air dari dalam bahan sehingga kadar air bahan menjadi rendah dan tidak tersedia untuk digunakan mikroorganisme. Selain itu menurut Desrosier (2008), kadar air produk pangan dipengaruhi oleh proses pemasakan karena kadar air bahan akan mengalami penurunan selama proses pemasakan. Proses yang terjadi yaitu panas yang ditimbulkan oleh pemasakan masuk ke dalam bahan yang kemudian menggantikan kandungan air yang keluar menjadi uap.

\section{Kadar tanin}

Kadar tanin tertinggi terdapat pada pelakuan B yaitu perlakuaan perbandingan daging buah keluwak dan gula pasir 1:1, yaitu sebesar $29.4 \%$, sedangkan kadar tanin terendah terdapat pada perlakuan kontrol yaitu sebesar $24.63 \%$. Tanin sebagai senyawa polifenol yang memiliki berat molekul tinggi dan mempunyai gugus hidroksi dan gugus lainnya sehingga bisa membentuk kompleks (Danarto dkk, 2011). Menurut Artati dan Fadilah (2007) bahwa pengambilan tanin dari suatu senyawa dapat dilakukan dengan ekstraksi salah satunya yang berpengaruh adalah jenis pelarut yang digunakan pelarut air. Tanin tidak larut dalam kloroform, petroleum eter dan benzene. Berdsarkan struktur tanin dibedakan menjadi dua kelas yakni tanin terkondensasi dan tanin terhidrolisis.

\section{Tanin}

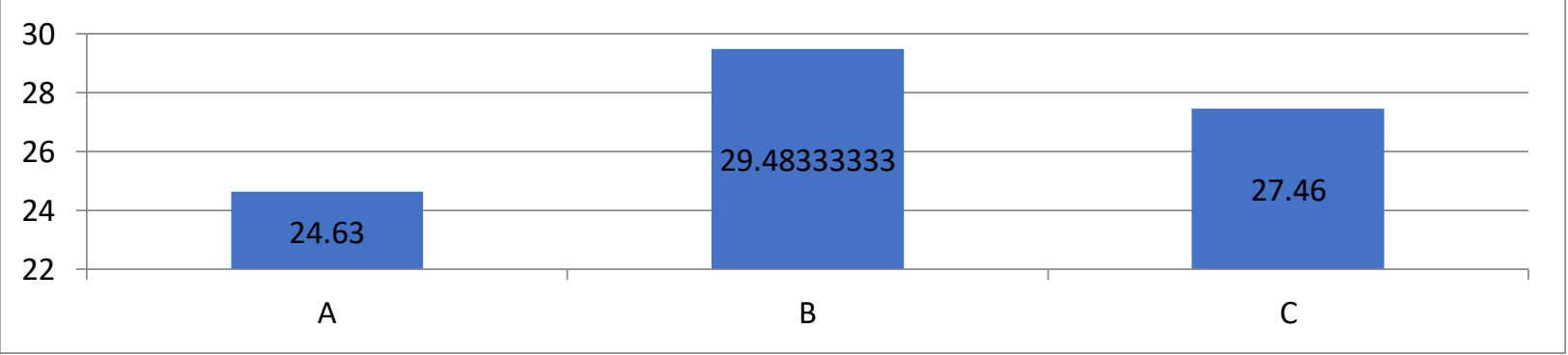

Gambar 3. Kadar tanin keluwak instan

\section{Kadar asam sianida}

Hasil analisa kadar asam sianida tertinggi pada perlakuan B 1:1 yaitu 27.85 dan terendah pada perlakuan A kontrol $20.45 \%$. Menurut Christine (2017) menyatakan bahwa semakin tinggi konsentrasi antibakteri yang ditambahkan, maka akan semakin tinggi pula aktivitas antibakteri yang ditunjukkan, karena biji kluwek memiliki khasiat sebagai antimikroba atau pengawet pangan yaitu kandungan asam sianida, tanin dan asam hidnokarpat dan sebagainya. Menurut Diah (2012), kandungan sianida adalah suatu asam lemah yang berbentuk cairan pada suhu kamar mempunyai bau yang khas apabila terbakar akan mengeluarkan warna biru. Pada keluwak ini mengandungan asam sianida yang sifat beracun. Biji pangi yang lebih tua mengandung ginokardin yang lebih sedikit dibandingkan dengan biji yang lebih muda (Elite dkk, 2017). 


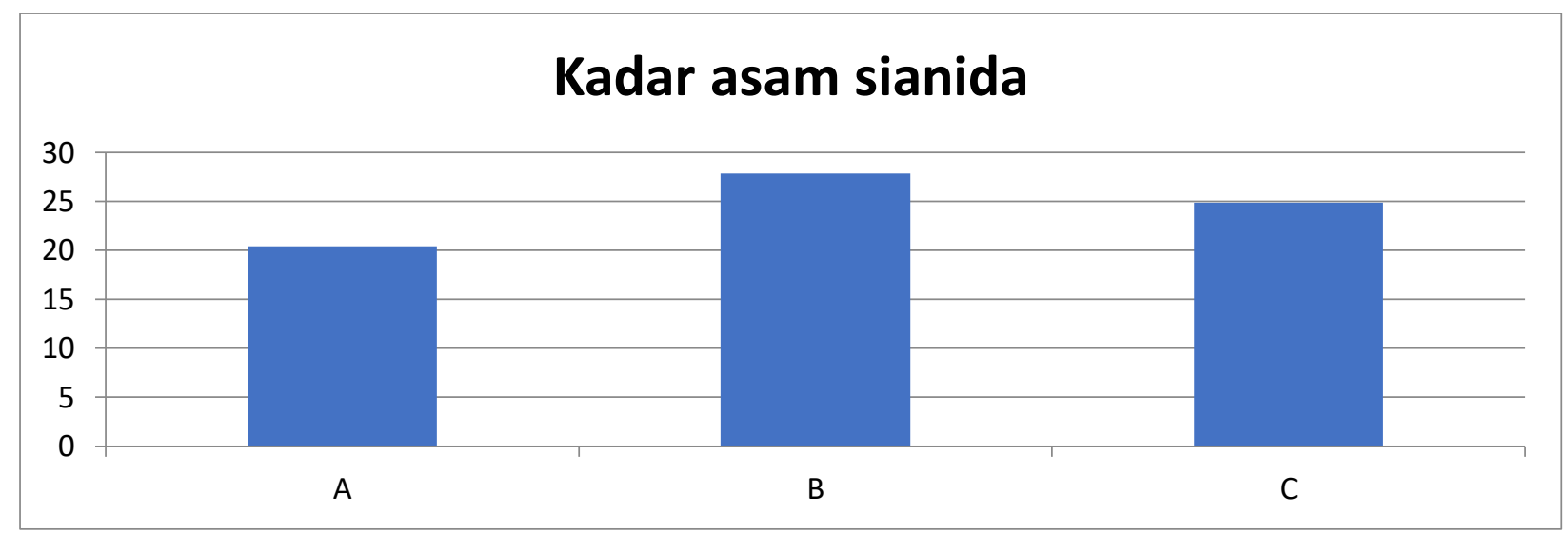

Gambar 4. Kadar asam sianida keluwak instan

\section{Respons wanita tani terhadap kajian materi}

Respons wanita tani terhadap kajian dengan metode wawancara dalam bentuk kuisioner 25 responden mendapat respon yang baik. Umur produktif sangat mempengaruhi kemampuan berusaha tani responden wanita tani. Tingkat pendidikan responden masih bervariasi. Jumlah tanggungan keluarga tergolong besar 0-5 orang $(95 \%)$. Tanggungan keluarga merupakan sumber tenaga kerja dalam kegiatan usaha taninya. Luas lahan berkisar 0.5-0.75 ha sebanyak 95\%, luas lahan sebagai sarana untuk mengelola dan mengembangkan ide-ide baru atau inovasi yang diperoleh.

\section{Evaluasi penyuluhan pertanian}

Evaluasi penyuluhan terhadap kegiatan penyuluhan sasaran yang ingin dicapai adalah pengetahuan, keterampilan dan perubahan sikap petani sehingga mempunyai kemampuan menerima dan melaksanakan suatu inovasi baru dan dapat meningkatkan pendapatan keluarganya. Pendekatan melalui pendekatan kelompok dan perorangan.

\section{Tingkat pengetahuan}

\section{Evaluasi awal}

Jumlah skor : 149

Skor tertinggi : $25 \times 5 \times 3=375$

Skor terendah: $25 \times 5 \times 1=100$

$$
\frac{149}{375} \times 100 \%=39.73 \%
$$

Bila digambarkan dalam garis kontinum sebagai berikut:



Gambar 5. Garis continum pengetahuan awal

\section{Evaluasi akhir}

$$
\text { Jumlah skor }=\frac{332}{375} \times 100 \%=88 \%
$$

Kalau digambarkan dalam garis kontinuum sebagai berikut:

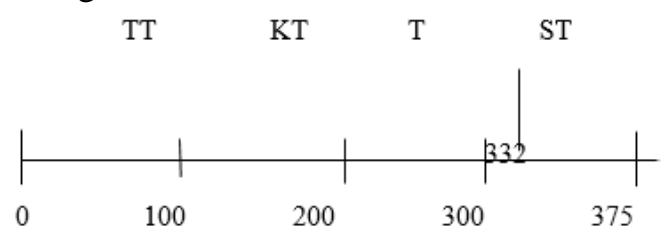

Gambar 6. Garis continum tingkat pengetahuan pada evaluasi akhir petani responden

\section{Sikap petani responden}

\section{Analisis hasil evaluasi}

(SS) sangat setuju : 4

(S) setuju : :3

(KS) Kurang setuju : 2

(TS) Tidak setuju : 1

\section{Evaluasi awal}

Jumlah skor : 208

Skor tertinggi : $25 \times 5 \times 3=375$

Skor terendah : $25 \times 5 \times 1=100$

$$
\frac{208}{375} \times 100 \%=55 \%
$$

Bila digambarkan dalam garis continuum adalah: 


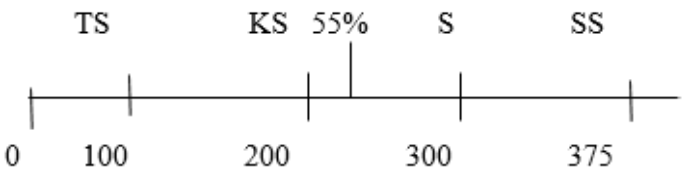

Gambar 7. Garis continuum sikap petani responden pada evaluasi awal.

\section{Evaluasi akhir}

Jumlah skor : 329

Skor tertinggi : $25 \times 50 \times 3=375$

Skor terendah : $25 \times 5 \times 1=100$

$$
\frac{329}{375} \times 100 \%=87.73 \%
$$

Kalau digambarkan dalam garis continuum adalah sebagai berikut :

TS

KS $\quad$ S $\quad 87,73 \% \quad$ SS

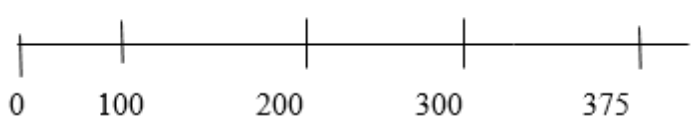

Gambar 8. Garis continum pada evaluasi akhir

\section{Keterampilan}

(ST) Sangat Terampil : :4

(T) Terampil : 3

(KT) Kurang Terampil : 2

(TT) Tidak Terampil $: 1$

\section{Evaluasi awal}

Jumlah skor : 155

Skor tertinggi : $25 \times 5 \times 3=375$

Skor terendah : $25 \times 5 \times 1=100$

$$
\frac{155}{375} \times 100 \%=41.33 \%
$$

Kalau digambarkan dalam garis continuum adalah sebagai berikut :

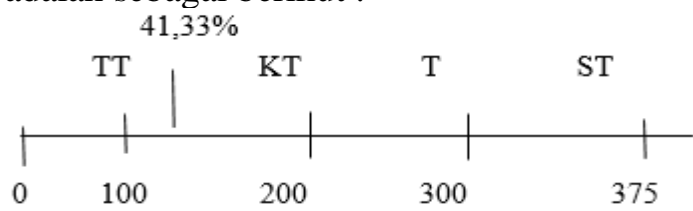

Gambar 9. Garis continuum keterampilan pada evaluasi awal

\section{Evaluasi akhir}

Jumlah skor : 338

Skor tertinggi : $25 \times 5 \times 3=375$

Skor terendah : $25 \times 5 \times 1=100$

$$
\frac{338}{375} \times 100 \%=90.13 \%
$$

Kalau digambarkan dalam garis continuum adalah sebagai berikut :



Gambar 10. Garis continuum keterampilan pada evaluasi akhir.

Hasil pada Tabel 1 dibawah ini bahwa tingkat perubahan pengetahuan petani responden meningkat sebesar $33.25 \%$, sikap $30.25 \%$ dan keterampilan $45.67 \%$. Perubahan perilaku tersebut dapat asumsikan bahwa penyuluhan dapat diterima oleh responden.

Tabel 1. Hasil evaluasi penyuluhan di Kelurahan Borongloe, Kecamatan Bontomarannu, Kabupaten Gowa.

\begin{tabular}{lcccccc}
\hline \multirow{2}{*}{ Uraian } & \multicolumn{2}{c}{ Pengetahuan } & \multicolumn{2}{c}{ Sikap } & \multicolumn{2}{c}{ Keterampilan } \\
\cline { 2 - 7 } & Jumlah & $\%$ & Jumlah & $\%$ & Jumlah & $\%$ \\
\hline Nilai maksimal & 375 & 100.00 & 375 & 100.00 & 375 & 100.00 \\
Tes awal & 149 & 39.73 & 208 & 55.00 & 155 & 38.75 \\
Tes akhir & 332 & 83.00 & 329 & 82.25 & 338 & 84.50 \\
Perubahan perilaku & 133 & 33.25 & 121 & 30.25 & 183 & 45.75 \\
\hline
\end{tabular}

\section{Efektivitas penyuluhan}

Menurut Daniel dkk (2006), .efektivitas penyuluhan tehadap evaluasi penyuluhan merupakan salah satu bagian untuk menentukan efektivitas dan dampak penyuluhan sesuai dengan tujuan yang ingin dicapai. Aspek yang diukur dalam pelaksanaan penyuluhan adalah efektivitas program penyuluhan dan perubahan perilaku responden .

$$
\begin{aligned}
\text { Efektifitas penyuluhan } & =\frac{P s-P r}{(n .4 . Q)-P r} \times 100 \% \\
& =\frac{999-562}{(20.4 .15)-562} \times 100 \% \\
& =\frac{437}{1200-562} \times 100 \% \\
& =68.59 \%
\end{aligned}
$$

Hasil perhitungan tersebut diatas, efektivitas penyuluhan yang telah dilaksanakan berada pada kategori efektif dengan skor $68.50 \%$. 


\section{KESIMPULAN DAN SARAN}

\section{Kesimpulan}

1. Pembuatan keluwak instan sebagai pengawet dapat dibuat dengan tahap perendaman biji keluwak, pencucian, pemeraman, pencacahan daging buah keluwak, pencampuran dengan gula pasir, dan pemasakan hingga kadar airnya sangat rendah

2. Kadar air tertinggi terdapat pada pelakuan B yaitu perlakuaan perbandingan daging buah keluwak dan gula pasir 1:1, yaitu sebesar $8.89 \%$, sedangkan kadar air terendah terdapat pada perlakuan kontrol yaitu sebesar $7 \%$. Kadar tanin tertinggi terdapat pada pelakuan B yaitu perlakuaan perbandingan daging buah keluwak dan gula pasir 1:1, yaitu sebesar 29.4\%, sedangkan kadar tanini terendah terdapat pada perlakuan kontrol yaitu sebesar $24.63 \%$.

3. Wawancara dalam bentuk kuisioner 25 responden mendapat respon yang baik. Hasil efektivitas penyuluhan yang telah dilaksanakan berada pada kategori efektif dengan persentase skor $68.50 \%$. Penyuluhan tersebut dibutuhkan oleh masyarakat.

\section{Saran}

Pada penelitian selanjutnya, sebaiknya ditambahkan jenis gula/pemanis lain pada tiap perlakuan, sehingga dapat dilihat pengaruh bahan pemanis lain terhadap kandungan kadar air, kadar tanin, dan kadar asam sianida

\section{DAFTAR PUSTAKA}

Artati, Enny Kriswiyanti dan Fadilah, 2007. Pengaruh kecepatan Putar Pengadukan dan Suhu Operasi pada Ekstraksi Tanin dari Jambu Mete dengan Pelarut Aseton. EKUILIBRUM 6(1):33-38.

Christine Fransin Mamuaja, Frans Lumoindong, 2017. Aktivitas Anti Mikroba Ekstrak Biji Keluwak (pungi edule) sebagai Bahan Pengawet alami bakso ikan tuna,
Universitas Sam Ratulangi, Manado Jurnal PHPI volume 20 no 3.

Daniel,M., Darmawati, dan Nieldalina, 2006. PRA (participatory Rural Appraisal), Pendekatan Efektif Mendukung Penerapan Penyuluhan Partisipatif dalam upaya percepatan pembangunan pertanian. Bumi Aksara, Jakarta.

Desrosier, Norman W. 2008. Teknologi Pengawetan Pangan. Ed. Ke-3. Penerjemah: Muchji Miljohardjo.Jakarta: UI-Press.

Danarto, Y.C, Muljadi, Kartikaningsih, D dan Arwan, M., 2011. Pengambilan Tanin dari Kulit Kayu Bakau dan Pemanfaatannya sebagai Adsoben Logam Berat Timbah $(\mathrm{Pb})$ dan Tembaga $(\mathrm{Cu})$ Prociding RAPI IX Surakarta:UMS.

Diah Irawati Dwi Arini, 2012. Potensi Pangi (Pangium edule Reinw) sebagai bahan pengawet alami dan prospek pengembangannya di Sulawesi Utara, Balai Penelitian Kehutanan Manado Jurnal Volume 2 No 2.

Elite Gizwati Samudry, A Sukainah dan Amirah Mustarin, 2017. Analisis Kualitas Keluwak (pangium edule Reinw) Hasil Fermentasi menggunakan media tanah dan abu sekam, Fakultas Pertanian Universitas Negeri Makassar, UNM. Jurnal Pendidikan Teknologi Pertanian, Vol 3 (2017) 25:33.

Siregar, Tuti Hartati, dan Nandang Priyanto. 2007. Pengaruh Tanin Kluwak Sebagai Pengawet Ikan.Jurnal Pascapanen dan Bioteknologi.Jakarta Balai Besar Riset Pengolahan Produk dan Bioteknologi Perikanan.

Subiandono, E. dan Heriyanto, N.M., 2009. Kajian Tumbuhan Obat Akar Kuning (Arcangelisia flava Merr.) di Kelompok Hutan Gelawan, Kabupaten Kampar, Riau. Buletin Plasma Nutfah Vol. 15. No.1. 43-48. 